\title{
Fruit or Vegetable
}

National Cancer Institute

\section{Source}

National Cancer Institute. Fruit or Vegetable. NCI Thesaurus. Code C1945.

Food substances obtained from plant source. 